\title{
TEACHERS AND CURRICULUM KAIAKO ME TE MaRAUtAnga
}


EDITOR:

Clive McGee

Editorial Committee:

Marilyn Blakeney-Williams

Nigel Calder

Kerry Earl

Philippa Hunter

Dawn Penney

Kirsten Petrie

Merilyn Taylor

Bill Ussher

\section{Cover Design}

Donn Ratana

\section{Layout AND Design}

Barbara Hudson

EDITORIAL CORRESPONDENCE AND

MANUSCRIPTS SUBMITTED FOR PUBLICATION SHOULD BE ADDRESSED TO:

\section{Research Manager}

Wilf Malcolm Institute of Educational

Research

Faculty of Education

The University of Waikato

Private Bag 3105

Hamilton 3240.

email:wmier@waikato.ac.nz

\section{Website:}

http://education.waikato.ac.nz/research/ publication/

BOOKS FOR REVIEW SHOULD BE SENT TO: Research Manager

Wilf Malcolm Institute of Educational

Research

Faculty of Education

The University of Waikato

Private Bag 3105

Hamilton 3240

email:wmier@waikato.ac.nz

\section{BUSINESS CORRESPONDENCE:}

orders, back orders, subscriptions, payments and other enquiries should be sent to:

\section{Teachers and Curriculum}

Hamilton Education Resource Centre PO Box 1387

Hamilton

email: janh@waikato.ac.nz

\section{SUBSCRIPTIONS:}

within New Zealand \$25 (includes postage) overseas $\$ 40$ (includes postage)

\section{COPYRIGHT:}

Faculty of Education

The University of Waikato

\section{TEACHERS AND}

Curriculum

VOLUME 122011

Contents

NOTES FOR CONTRIbUtors

2

EDITORIAL

Clive McGee

3

History in the New Zealand Curriculum: Discourse Shaping and Key Competencies Possibilities

Philippa Hunter

Learning to think as an effective mathematics teacher: Teacher educator impacts on curriculum knowledge and learning to teach

Mary Hill, Lexie Grudnoff and Fiona Ell

Literacy and numeracy standards: Recent constructions within the political, business and media discourses in New Zealand

Margaret Walshaw and Roger Openshaw

Authentic Assessment in Performance-based Subjects

John Williams and Dawn Penney

From classroom teacher to teacher educator: Generating PCK through action research

Anne Hume

Teachers' perspectives of professional development for effecting change in Māori medium classrooms: A mathematics experience

Ngarewa Hawera and Merilyn Taylor

The Principles in the New Zealand Curriculum: What sense do student teachers make of them?

Frances Edwards

A Critical Analysis Process - bridging the theory to practice gap in senior secondary school physical education

Lorna Gillespie and Sue McBain

Teacher Educators Talk About Enduring Understandings Kerry Earl, Jenny Ferrier-Kerr and Bill Ussher

Rethinking The Role Of Counting In Mathematics Learning

Jenny Young-Loveridge

A Research Note: A Regional Response to National Concerns in Teacher Education Anne-Marie Hunt 
TeAchers ANd Curriculum is an annual publication of the Faculty of Education, The University of Waikato, Hamilton, New Zealand.

It includes articles about curriculum issues, research in the area of curriculum and informed curriculum practice. Reviews of curriculum related books may also be included.

ISSN 1174-2208

\section{NOTES FOR CONTRIBUTORS}

Teachers and Curriculum provides an avenue for the publication of papers that:

- raise important issues to do with the curriculum

- report on research in the area of curriculum

- provide examples of informed curriculum practice

- review books that have a curriculum focus.

This peer reviewed journal welcomes papers on any of these from tertiary staff and students, teachers and other educators who have a special interest in curriculum matters. Papers on research may be full papers, or if time or space is at a premium, research notes, that is a 2,000 word summary.

\section{SUBMITTING ARTICLES FOR PUBLICATION}

The editorial committee encourages contributors to ask colleagues to comment on their manuscripts, from an editorial point of view, before submission for publication.

\section{LENGTH}

Manuscripts should not normally exceed 7,000 words, including references and appendices. An abstract must be provided. Abstracts should not be more than 100 words.

\section{MetHOd OF SUBMITTING A PAPER}

Please provide copy in 12 point type in a font compatible with the use of macrons (preferably Helvetica Maori or Times Maori) with line and a half spacing for the main text, and with $20 \mathrm{~mm}$ margins on all edges. Word files are preferred. Please do not include running headers or footers, Follow the style of referencing in the Publication Manual of the American Psychological Association (APA), 5th edition with references in a reference list at the end of the manuscript, rather than footnotes. Manuscripts not submitted in accordance with the above guidelines will be returned to authors for amendment.

\section{Covering LetTer}

When submitting a manuscript to Teachers and Curriculum, authors must, for ethical and copyright reasons, include in a covering letter a statement confirming that (a) the material has not been published elsewhere, and (b) the manuscript is not currently under consideration with any other publisher.

\section{DATE FOR SUbMISSION}

Manuscripts may be submitted at any time.

\section{COPYRIGHT}

Copyright of articles published in Teachers and Curriculum rests with the Faculty of Education, The University of Waikato. Requests to reprint articles, or parts of articles must be made to the Editor via the Hamilton Education Resource Centre.

Email: barbh@waikato.ac.nz 


\section{A Critical Analysis Process - BRIDGING THE THEORY TO PRACTICE GAP IN SENIOR SECONDARY SCHOOL PHYSICAL EDUCATION}

LORNA GiLleSPIE

\section{DePARTMENT OF SPORT AND LeISURE \\ FACULTY OF EDUCATION \\ THE UNIVERSITY OF WAIKATO}

\section{Sue McBaIN}

SCHOOL OF SCIENCES

aNd Physical EDUCATION

UNIVERSITY OF CANTERBURY

\begin{abstract}
Many contemporary international physical education curriculum documents have a socio-cultural and critical orientation, which promotes the implementation of a critical pedagogy. Aotearoa New Zealand is no exception. This paper reflects our ongoing efforts to address, from a practical pedagogic perspective, the implementation of a socio-critical curriculum and articulation of critical pedagogy in senior secondary school physical education. We draw attention to the challenging nature of articulating critical pedagogical theory in school practice. We identify the understanding and interrelationship of social construction, multiple perspectives, and hegemony as key aspects in the teaching and learning process that support the development of student teachers' criticality and in turn their ability to critically analyse. We present these concepts as part of a Critical Analysis Process, a model that is designed to facilitate questioning by student teachers of their own status quo beliefs and practices. It is a model that is a work in progress.
\end{abstract}

\section{INTRODUCTION}

In Aotearoa New Zealand, programmes of physical education for students from Year 1-13 are constructed in schools by reference to the learning requirements outlined in the New Zealand Curriculum (NZC; Ministry of Education [MoE], 2007) and prior curriculum document Health and Physical Education in the New Zealand Curriculum (MoE, 1999). The 1999 curriculum document signalled a more sociocultural and critical orientation to physical education, based on both humanistic and critical traditions. This prompted teachers to consider employing pedagogical approaches that would "encourage students not only to experience and learn through physical activity, games and sport but to ask critical questions about physical activity within society, locate themselves in their community" (Culpan \& Bruce, 2007, p. 5).

Physical education curriculum documents prior to 1999 followed international trends that they were arguably more suited to scientised, technocratic and performance pedagogies (Culpan, 2004; Fitzpatrick, 2010). In contrast, the implementation of the Health and Physical Education in the New Zealand Curriculum (MoE, 1999) challenged teachers to become more conversant with political and potentially oppressive practices within physical education and the movement culture. Teachers of physical education, in particular senior physical education, were therefore encouraged to develop a socio-critical perspective and adopt inquiry-based and critical pedagogical approaches to their teaching and learning programmes (Culpan \& Bruce, 2007; Fitzpatrick, 2010; Wright, 2004).

While literature with a focus on the theoretical understandings of critical pedagogy is relatively accessible (see for example, Breunig, 2009; Shor, 1996; Sweet, 1998) there is considerably less literature that addresses how critical pedagogy can be applied in classroom practice. Studies relating to physical education that examine critical pedagogy in practice are predominantly confined to physical education teacher education (PETE) and provide limited insight into how teachers might move critical pedagogy into their practice in secondary schools (Fitzclarence \& Tinning 1990; Macdonald \& Brooker, 1999; Macdonald, 2002; O'Sullivan, Siedentop, \& Locke, 1992; Ruiz \& Fernandez-Balboa, 2005). These studies incorporate the examination of physical education teacher educators' critical pedagogical praxis, and report that many participants struggled to engage in critical praxis and often reverted to transmission-based pedagogy.

The movement culture and sport offer a multitude of opportunities for students to critically engage with practices and issues. Kirk (2006) suggests physical education is well placed to take up the challenge of critically engaging with the realm of sport and its global and pervasive influence. Similarly, Laker (2003) comments on the possibility of teachers "helping their students to become critical consumers and knowledgeable managers of their own physically active lifestyles" (p.157). However, the articulation of critical pedagogy theory in practice continues to be problematic, with questions raised by a range of scholars regarding the challenges of implementing a critical pedagogy and a lack of practical application. Both Tinning (2002) and Macdonald (2003) question the relevance of critical pedagogy and suggest the practicalities of implementation need careful consideration. Others (see for example, Biesta, 1998; Kohli, 1998) see the relationship between theory and practice in relation to critical pedagogy as complex and in need of further deconstruction.

Various commentators (Breunig, 2009; Green, 1998; Kanpol, 1999; Kincheloe, 2004) have suggested that the intent of critical pedagogy needs to be more explicitly articulated to translate to practices that could contribute to a more socially just and equitable world. In addition, Green (1998) contends that a focus on both pedagogy and learning is needed in order for critical pedagogy is to be realised as educational praxis. He emphasised the need to bring together academic work in education with education theory and classroom practice. The work reported in this paper endeavours to bridge this theory-to-practice gap. While this paper focuses on pursuing these issues in a New Zealand setting, we believe our scrutiny is able to 
contribute to international literature and debates.

In the last decade the New Zealand physical education profession has grappled with the challenges of the philosophical shift of moving to more socio-critical teaching approaches. Anecdotal evidence from discussions with teachers suggest many teachers have struggled to develop and implement meaningful physical education programmes when they have a socio-critical curriculum. We have approached this issue from multiple standpoints over time, having been involved in initial teacher education, teacher professional development, secondary physical education teaching and physical education advisory roles. This has meant we have needed to not only develop our own practice as educators in a range of roles, but also consider how to successfully enable secondary school students, teacher education students and practicing physical education teachers to understand and implement a sociocritical physical education curriculum.

This paper reflects our ongoing efforts to address, from a practical pedagogic perspective, the implementation of a socio-critical curriculum and articulation of critical pedagogy in senior secondary school physical education. In doing so, we have sought to devise processes that support the development of student criticality and ability to critically analyse in senior physical education programmes by employing a critical pedagogy. Necessarily, we begin by reviewing understandings of "critical pedagogy" and clarifying how it is conceptualised in our work.

\section{Positioning in Critical Pedagogy}

Pedagogy concerns teaching and learning, and the interrelated nature of the relationship between them. Watkins and Mortimore (1999) define pedagogy as "any conscious activity by one person designed to enhance learning in another" (p. 17). Pedagogy, by the nature of its meaning, brings together theory and practice. In the realm of critical pedagogy, praxis - the complex interrelationship of theory and practice-involves working towards an outcome of informed action. A range of definitions exists for critical pedagogy, many of them relating to influential critical theorists, with critical pedagogy viewed as the analytical tool of critical theory applied to pedagogy. Tinning (2002) refers to the critical pedagogy "big tent" - a phrase coined originally by Gore (1993) to describe the breadth of perspectives on critical pedagogies. This paper has arisen from our work positioned within the "big tent". While there is no single definition for critical pedagogy, on analysis, common themes are apparent. One of these is that critical pedagogy is concerned with coming to understand the interrelationships of ideology, power, and culture, with the broad intent of critical pedagogy being to contribute to a more socially just world (see for example, Breunig, 2009; Kanpol, 1999; Kincheloe, 2004; Kirk, 2006 Leistyna \& Woodrum, 1996). Critical pedagogy has evolved and continues to do so. This premise has guided our work.

We have pondered the question that Tinning (2002) poses: "does the implementation of a socially critical curriculum require a critical pedagogy?" (p. 229). We propose that to implement a socially critical curriculum necessitates an understanding of, at least, the potential of the application of critical pedagogy. However, we are also mindful of Cassidy's (2000) caution that implementing a socially critical pedagogy in postmodern times is no easy task, nor is there one right way to do so.

An important aspect of our approach aligns with Kirk's (2006) commentary on critical pedagogy, specifically, "cultural critique" (p. 257). Kirk views "cultural critique" as one of the key features of a critical pedagogy for physical education that centres on education for social change. Critique is more than simply criticism and, according to Kirk, aims to

... assist people to see beyond the obvious, the commonplace, and commonsense of everyday life in order to better understand the interrelatedness of human activity on a number of levels. At the heart of this notion of cultural critique is an individual's willingness to see beyond surface appearances and to act constructively and positively in meeting new challenges. (p. 257)

This tenet is reflected throughout the NZC (MoE, 2007) and is particularly pertinent in the Key Area of Learning of Sport Studies, which states: "In sports studies ... students ... investigate and critically appraise the educative value of sport and consider the effects of sport from social, cultural and scientific perspectives" (MoE, 1999, p. 44). The critical pedagogy inherent within the NZC provides a means through which physical education can contribute to sustaining sport as the humanistic goal of a moral practice and is seen as an appropriate vehicle for learning in, through and about movement (Kirk, 2006). The need for students to develop their criticality in order to engage in cultural critique and meet the intent of the NZC (MoE, 2007) was instrumental in creating a need for the critical analysis process explored in this paper.

\section{Critical Pedagogy In POSTMODERN TIMES}

When critical pedagogy and postmodernism are examined, tensions are evident. Challenges are made by a number of scholars (see for example, Biesta, 1998; Burbules \& Rice, 1991; Burbules \& Berk, 1999; Tinning, 2002; Weiler, 1991) who question the contradiction between the goals of critical pedagogy and postmodernism. In particular we acknowledge there is substance to the postmodern critique of objective realities associated with the critical theory, and therefore strive to accommodate diverse realities through employing constructivist pedagogies. In addition, we concede there is potential for postmodern critical pedagogy to be seen as an ally of new capitalism and therefore there is a need to tread carefully in enabling the development of critical analysis abilities within physical education programmes. We align with Pinar, Reynolds, Slattery and Taubman (1996), who suggest that postmodern critical pedagogy has a focus on the relationship between the self and others, and therefore do not view critical pedagogy and postmodernism as mutually exclusive. Friere (cited in Roberts, 2000) acknowledged the multiple realities and strongly encouraged educators to become "more tolerant, open and forthright, critical, curious and humble" (p. 112).

Tinning (2002) acknowledges the criticisms of critical pedagogy and its articulation, making a "case for a 'modest pedagogy' that avoids some of the pitfalls identified" (p. 226). Tinning describes this modest pedagogy as having a range of forms, as a way of orienting thinking about "what claims we can make in the name of pedagogy that works for the social reconstructivist education project" (p. 236).

In the development of our Critical Analysis Process (CAP), we have been mindful of Tinning's (2002) encouragement to consider a modest pedagogy. We have endeavoured to retain a sense of realism in attempting to enable both physical education teachers and senior secondary physical education students to develop understanding of the possibilities of what is, for many, a new and challenging way of looking at the movement culture and its place in their lives. We continue to work on these developments and by no means claim we have "arrived" at a finished 
product. In developing the CAP outlined in this paper, we have attempted to ascertain the key aspects that "give life" to a critical pedagogy within physical education in secondary schools in particular.

We advocate a pedagogy underpinned by understanding of critical theory and critical pedagogy, a pedagogy that focuses on the development of student's ability to be critical, as supported by the intent of critical pedagogy-particularly in regards to the understanding of self, others, society and their interrelatedness. The CAP strives to give students opportunities to make meaning of and better understand their world, and to challenge these understandings.

We also acknowledge that the context of school is one of many contexts in which students will be exposed to power relations. Schools tend to reinforce meanings related to identity and can be places of control and compliance. However, this offers a familiar context for critical analysis and can be the beginning of realisation for students that they can be part of creating a more just society. Teachers need to understand what is at stake and, as Penney and Jess (2004) suggest, make "a commitment to the development of informed learners capable of critical engagement with activity agendas, opportunities and barriers experienced throughout their lives" ( $p$. 272). We concur with the need to develop critical and discerning considerers of, and participants in, the movement culture.

\section{Critical COnStructivism as a PEDAGOGICAL FRAMEWORK FOR} the Critical Analysis Process

The Critical Analysis Process is intended to provide students with opportunities to question the status quo, develop their criticality and explore how they might contribute to change (Hinchey, 2004). Furthermore, we believe that the process of developing criticality is "a complex and messy one which takes place over a period of time and is one that cannot be developed through coercion or imposition of ideas" (Nemiroff, 1992, p. 59). Given this, we argue that a critical constructivist scaffolding, as embedded in the CAP, enables students to develop their criticality by utilising, sharing and reflecting on their own collective experiences and activities, and engaging students in "connecting their experiences in the classroom to their real lives" (Azzarito \& Ennis, 2003, p. 179).

The critical constructivist framework is described as a "unified theory" which synthesises the central tenets of critical and constructivist theory (Kincheloe, 2005). There are considerable synergies between the critical and constructivist theories, as constructivists consider that "objective reality is not perceived directly and that we construct our view of the world based on sensory input of all kinds and the interaction of this input with pre-existing knowledge" (Pritchard \& Woollard, 2010, p. 8). When applied to teaching and learning, those who subscribe to constructivist theory "explore the connections among knowledge, meaning and learning" (Azzarito \& Ennis, 2003, p. 179). Consequently, critical constructivists explore how socio-cultural factors, including hegemonic relationships, influence knowledge and meaning in society. Critical constructivists ask questions such as "who and what influences the production of knowledge and ask us to examine what we consider as reality" (Kincheloe, 2005, p. 2). Aligning with this, the CAP asks both teachers and students to examine hegemonic social relationships within all aspects of their lives and subscribe to constructivist teaching and learning principles.

While Kincheloe (2005) applied critical constructivist theory to teacher education, encouraging pre-service teachers to question power relations and knowledge development in education, the CAP asks secondary school teachers and students to analyse power relationships and knowledge construction in their immediate lives, thus beginning a process of becoming critically conscious of their "own being in the world" (Nemiroff, 1992, p. 58). We suggest that applying the CAP to examine contemporary movement cultures gives students the opportunity to begin to understand who and what shapes their understanding and perceptions of their own and other realities and the ways in which this may occur. Congruent with Duncum (2008), we were essentially asking students to undertake a self-critique, a challenging task "which is difficult even for mature adults" (Duncum, 2008, p. 249). It is desirable that teachers facilitate this process through a non-threatening and gentle process of construction and reflection. Anecdotal evidence and feedback from colleagues has informed us that students are less likely to respond positively to the use of authoritarian or transmission pedagogies, as these pedagogies are essentially counterproductive to the development of student criticality.

\section{The Critical Analysis Process: An overview}

We now describe the working model that has been evolving as a way of conceptualising the critical thinking, reflection and actions of students. The initial phases of the Critical Analysis Process model (CAP) explore the application of academic knowledge of social construction and hegemonic social relationships through reflection on senior secondary students' personal movement experiences. These experiences are derived from a range of movement-related contexts. In subsequent stages of the CAP, students examine the consequences of hegemonic social relationships and explore actions for social justice. While the CAP model is presented as a linear process in Table 1, we view the various parts (or stages) of the model as belonging to a complex whole. The model represents how participants weave through the stages in a non-linear fashion in response to student learning needs. 


\begin{tabular}{|c|c|}
\hline The process & $\begin{array}{l}\text { Questions, strategies, actions to promote critical thinking, reflection, } \\
\text { action. } \\
\text { Select questions relevant to the activity }\end{array}$ \\
\hline 1. Initial learning experience & $\begin{array}{l}\text { Students participate or engage with any experience that is relevant for analysis. } \\
\text { This can include but is not limited to movement experiences in class and personal } \\
\text { experiences, media activities such as adverts, articles and reporting, films, books, stories, } \\
\text { texts, etc }\end{array}$ \\
\hline $\begin{array}{l}\text { 2. Describe } \\
\text { What you see or experienced }\end{array}$ & $\begin{array}{l}\text {-What do you see in the activity, situation, picture, video, and article? What did you or } \\
\text { others experience during the situation or activity? } \\
\text { - Who can you see in the activity, situation, picture, video, and article? } \\
\text { - Who's missing from the activity, situation, picture, video, and article? } \\
\text { - What messages do the activity, situation, picture, video, and article send? } \\
\text { - What is the intention or aim of this activity, situation, picture, video, and article? }\end{array}$ \\
\hline $\begin{array}{l}\text { 3. Identify assumptions, } \\
\text { stereotypes and social } \\
\text { construction theory } \\
\text { Applying social construction theory }\end{array}$ & $\begin{array}{l}\text { - What assumptions and stereotypes have been made by those involved directly or } \\
\text { indirectly in this activity, situation, picture, video, and article, including you? } \\
\text { - How have these assumptions and stereotypes been socially constructed and why? }\end{array}$ \\
\hline $\begin{array}{l}\text { 4. Identify and explain influences } \\
\text { Personal reflection on social } \\
\text { construction and understanding } \\
\text { multiple perspectives }\end{array}$ & $\begin{array}{l}\text { - What are my ideas about this activity, situation, picture, video, and article? } \\
\text { - Who and what has influenced my ideas about this? } \\
\text { - Who and what has influenced others' different ideas about this? } \\
\text { - Whose and what are the different points of view about this? }\end{array}$ \\
\hline $\begin{array}{l}\text { 5. Identify sociological ideas and } \\
\text { themes } \\
\text { Identify, name and define the } \\
\text { sociological themes and knowledge that } \\
\text { applies to this activity, situation, } \\
\text { picture, video, and article and as related } \\
\text { to others ideas. } \\
\text { - Name the topics and content you need } \\
\text { to know to complete the following } \\
\text { steps in the critical analysis process. }\end{array}$ & $\begin{array}{l}\text { For example: } \\
\text { Social construction of sport } \\
\text { Gender-masculinity, femininity, stereotypes, social construction } \\
\text { Commodification of the body, athletes, sport, sexuality } \\
\text { Sport and business and entertainment } \\
\text { Identity—individual, national, regional } \\
\text { Technocentricity—body as a machine } \\
\text { Body as a project } \\
\text { Sport as warfare } \\
\text { Sport as aggression, frustration release } \\
\text { Globalisation } \\
\text { Role of business and media in constructing the above }\end{array}$ \\
\hline $\begin{array}{l}\text { 6. Inquire and investigate: } \\
\text { Gather information and } \\
\text { evidence }\end{array}$ & $\begin{array}{l}\text { - What do others say in support of or disagreeing with different points of view related to } \\
\text { this topic } \\
\text { - Is there other evidence which supports or refutes differing points of view? (e.g. statistics) }\end{array}$ \\
\hline $\begin{array}{l}\text { 7. Understand the nature of the } \\
\text { relationships } \\
\text { Identify power relationships/hegemonic } \\
\text { social relationships }\end{array}$ & $\begin{array}{l}\text { - Who has the most and least influence in this situation? Who gets to make decisions? } \\
\text { - Who is advantaged and disadvantage by the relationships observed in this activity, } \\
\text { situation, picture, video, and article? } \\
\text { - Who has a vested interested in maintaining the status quo? } \\
\text { - Why is/are (people concerned) being portrayed in this way? } \\
\text { - Where am I located within the varying positions? }\end{array}$ \\
\hline 8. Consequences & $\begin{array}{l}\text { - What are the impacts/influences/consequences of these power } \\
\text { relationships/inequities/social injustices on self, others and society? }\end{array}$ \\
\hline $\begin{array}{l}\text { 9. Critical action } \\
\text { Consider change and Take action! }\end{array}$ & $\begin{array}{l}\text { - Consider all the discussion and information to this point: make a personal judgement or } \\
\text { develop a personal opinion/stance about the activity, situation, picture, video, and article } \\
\text { etc } \\
\text { - Examine the need for change and possibilities for individual and group action. }\end{array}$ \\
\hline
\end{tabular}

We now provide a brief outline of the stages and academic knowledge central to how students scaffold their increasing ability to critically analyse. The outline provides the basis for a later discussion of the usefulness of the model.

\section{STEP 1: THE INITIAL LEARNING EXPERIENCE}

The first step in the critical analysis process requires the teacher to create opportunities for students to engage in a shared experience or activity, which they can reflect on and/or investigate further. We agree with many of the constructivist theorists (see for example, Beard \& Wilson, 2002; Kraft \& Kielesmeier, 1995; Luckner \& Nadler, 1997; Prouty, Panicucci, \& Collinson, 2007) who believe experience is the most powerful learning tool available to teachers and suggest teachers develop suitable experiences for students to learn from. Within the CAP we suggest this is a blend of experiences which consist of active participation in sporting or physical activity and viewing sport media including YouTube clips, movies, and advertisements. 


\section{SteP 2: Describe}

Similar to Wright's (2004) and Fairclough's $(1992,1995)$ three-stage analysis process, we begin the reflection stage of the process with "describe". Students with little experience in critical thinking and analysis may find it difficult to notice "clues" central to such endeavours. Noticing how "language, image, frames, camera angles" (Wright, 2004, p. 184) and music are used are important clues to develop students' ability to critically analyse. Teachers who are introducing critical analysis to students can facilitate the describe phase of the process with some astute questions such as those outlined in the "describe" section in Table 1. This phase of the process can also be constructed as an inquiry where students collect quantitative data about a particular physical activity or sporting event or issue.

\section{StePS 3 AND 4: Making MEANING FROM EXPERIENCE; IDENTIFYING ASSUMPTIONS, STEREOTYPES, SOCIAL CONSTRUCTION AND PERSONAL INFLUENCES}

Through our experience of developing the CAP, we have found it desirable to provide students with an academic knowledge of social construction as central skills for critical analysis. The making-meaning steps consist of students identifying assumptions and stereotypes and understanding personal influences through application of social construction theory. The experience and describing components of the CAP on their own do not necessarily constitute learning, as we support Beard and Wilson's (2002) notion that learning is a linking process between action and thought. The linking of the experience and description with the thought, or the "making meaning" components of the CAP, utilises constructivist understandings of learning, encouraging students to draw on their and others' understandings to create new knowledge.

The analysis of assumptions and stereotypes are core content knowledge associated with the theory of social construction, giving students the opportunity to understand how knowledge is socially constructed and is a small step towards understanding social construction. For example, the widely held assumptions and stereotypes of thin $=$ fit $=$ healthy or unhealthy $=$ fat provide rich complexities to challenge dominant social construction and knowledges to broaden student's sociocultural understandings.

\section{SOCIAL CONSTRUCTION THEORY}

Explicit within Steps 3 and 4 is the understanding of social construction theory, a further aspect of the consciousnessraising process which can give voice to all students (Carlson, 1998). Not only are we asking the students to engage in a critical constructivist learning process, we are asking students to understand the theory of social construction as it applies to their lives. As most students have little knowledge and experience of the ways their environment shapes their reality, it becomes significant to develop modes of analysis to highlight the complex social construction process (Kincheloe, 2005), developing students' ability to understand how society shapes their reality.

Inevitably, developing understandings of social construction leads to questions and reflections about how students' personal lives are socially constructed and the consequences of this. Understanding that every person has a different view of reality, developed from the complex interplay of factors such as personal experiences, family, friends, gender, religion and environment, is an essential early step in the recognition of multiple perspectives (Azzarito \& Ennis, 2003; Cobb, 1996; Kincheloe, 2005; Light \& Wallian, 2008; Pritchard \& Woollard, 2010; Richardson, 2003). We suggest developing understanding of assumptions, stereotypes and multiple perspectives as part of social construction encourages students to make the familiar strange (Gorden, 2000) and view the world through "fresh eyes", something that is necessary in the development of criticality. Students who are closed to new ways of thinking may ignore or discredit other realities, hindering their ability to develop a critical consciousness and to critically analyse.

Throughout this process, students are simultaneously considering academic knowledge related to social construction and inevitably reflecting on their personal knowledge, resulting in the production of new knowledge. As Kincheloe (2005) discusses:

A key skill of a critical constructivist teacher involves nurturing this synthesis of personal experience and academic knowledge. Such a pedagogical act is extremely complex, and teachers must work hard to bring the different perspectives together. (p. 4)

Teacher-led collective dialogue can facilitate students' "making meaning" as both an individual activity in which participants draw on previous knowledge and a social activity where, through complex interactions with others, shared meaning is developed (Pritchard \& Woollard, 2010). For students, personal "making meaning" is a long and complex process requiring repetition and patience on the part of both teacher and learners.

\section{STEPS 5-8: UNDERSTANDING POWER AND HEGEMONY}

A critical constructivist framework is concerned with issues of power and inequality and the function power plays in "construction and validation processes" (Kincheloe, 2005, p. 3). Exploration of the ways processes privilege some and marginalise others is central, with critical constructivists asking questions such as who has the power to shape both individual and societal reality and who is marginalised by this process. In addition to understanding social construction, multiple perspectives and seeing the world with "fresh eyes", the understanding of hegemony is central to students' development of their criticality. Explicit teaching and learning activities to explore the nature of hegemonic social relationships alerts students to new ways of viewing the world, creating cognitive dissonance and fostering their criticality. Questions such as the following are used:

- Who has power and who is powerless in wider society, in the school, my sports team or in my family?

- How do powerful groups or people maintain power? Why?

- In each of these situations, who influences what we think and how?

We contend that questions such as these are explicitly teaching hegemonic concepts and are central to the development of students as "critical agents" (Nemiroff, 1992, p. 59). Initially deconstructing the impersonal and wider society, such as media, business, and government, and, subsequently, aspects of their own sphere of experience, including teacher-student relationships, bullying, friendships, experiences in sport, enables the students to develop their criticality, and a language to express their understanding of the nature of power relationships. Coherent with a critical constructivist framework, it is envisaged that teaching and learning activities used in this aspect of the CAP allow students to be active researchers, necessary for effective critical inquiry (Wright, 2004).

The CAP supports the development of students' develop democratic knowledges. Students are enabled to see the world afresh and to value forms of meaning 
making traditionally dismissed by dominant groups in society. Examining the "consequences" of the social construction of knowledge and hegemonic social relationships answers the "so what?" question of the CAP. It is this aspect of the CAP which gives students the opportunity to examine the authentic and lived experiences of those who are privileged and those who are marginalised in movement contexts, and it is this examination which prompts students to consider the consequences of hegemonic relationships. Through examining consequences, we strive to create cognitive dissonance to promote personal and emotional student responses. For example, as previously mentioned, the assumptions of thin $=\mathrm{fit}=$ healthy or unhealthy = fat, the consequences of which have the potential to be personally damaging to many. It is this realisation which often confronts students. We acknowledge that student responses to the consequences of hegemony are, and will be, varied as it is dialectically related to higher levels of moral reasoning based on students' internalised values and norms (Watkins, 2005) and, not all students will be concerned about those who are marginalised.

\section{Step 9: Critical action}

While the CAP's intention is to empower and enable students to make a difference in their world, we are not asserting taking action is a certainty, nor are we suggesting how and when this might be. The potential can be viewed as the production of difference, through the desire and ability to make a difference by acting for social justice. This is supported by Green (1998), who suggests that learning that emerges in physical education does so in ways that cannot always be predicted. Therefore we advocate that to teach for difference, we need to know how to teach for difference and with difference, with a view that action will be taken in some form, either immediately or in the future.

The steps in the CAP weave together to develop student skills which enable them to find a way of thinking and a voice which will "find three things simultaneously: find something to say, find a rhetorical style in which to speak and write, and find a conversation or 'truth game' to join" (Carlson, 1998, p. 541).

As suggested by Carlson (1998), employing Plato's rhetorical voices of the logos, thymos and mythos can contribute to the development of a

... hybrid voice that drifts across borders, one that interweaves voices of logos, thymos, and mythos and that shifts back and forth from analysis to anecdote, from theory to personal story-telling, from principled talk of social justice to personal and positioned expressions of outrage at injustice. (p. 542)

The CAP acknowledges a range of voices, experiences, perspectives and outcomes. It is intended that utilising the CAP will allow contradictions to emerge through engaging in dialogue with teachers and peers, encouraging "learners to think and enquire by asking thoughtful, open-ended questions and by encouraging them to ask questions of each other" (Pritchard \& Woollard, 2010, p. 69). It is intended that the pedagogy of the CAP is modest and playful, allowing students to explore ambiguities and accept the complexities of student attitudes (Duncum, 2009) while simultaneously engaging the development of the sociological imagination.

\section{Reflection on feedback about the CAP}

The process represented by CAP is primarily concerned with empowering students through developing knowledge and analytic skills "to assist people to see beyond the obvious, the commonplace, and common-sense everyday life in order to better understand the inter-relatedness of human activity on a number of different levels" (Kirk, 2006, p. 257). At this point in the development of the CAP we acknowledge that evidence related to our goals for the CAP is from an information action research process, which utilised student and teacher evaluations and our own reflections. This included students and teachers in school settings as well as those who have subsequently left school (from first being introduced to using the CAP) and are now in initial teacher education. Evidence to date suggests that the CAP does provide a useful structure to understand the process of critical analysis and application of social construction theory. For example, as a student commented: "Applying the process allowed me to see the issue from other people's perspectives, which group benefits and who does not and why/how society constantly reinforces particular values, beliefs and positions" (student 1).

In agreement with Kirk (2006), "students are seeing beyond the obvious" (p. 257), understanding the social construction of knowledge. The feedback also suggests that the CAP challenges students "to think about how [assumptions] have a flow on effect to others, putting themselves in a place of dominance over the others" (student 2) and promotes "the understanding of the consequences" (student 2) of assumptions and stereotypical viewpoints. Others commented that developing a critical consciousness had changed their perceptions on life and they now "tend to think critically about a lot of issues, whereas before probably I would not have questioned them" (student 3).

Teachers have found the teaching of the academic knowledge related to social construction and hegemony useful, with one teacher commenting, "once you've done the teaching of the basic [academic] skills and the CAP, students are able to apply them to everything they do" (teacher 1). It was reported that the CAP gave teachers and the students "a good framework to follow" (teacher 2), and that the CAP "is an extremely useful tool as it is logical, sequential, detailed and progressively helps students to step by step deconstruct many previously taken for granted assumptions" (teacher 3 ).

Teacher feedback suggests that future refinements of the CAP require "a greater emphasis on taking action" by "drawing on democratic ideals relating to developing within students a competence in active citizenship" (teacher 3) and another teacher commented that the process could be repetitious. The CAP is not linear and learners will weave around the process, dropping in out of each step as directed by dialogue and student needs.

The CAP is a modest (Tinning, 2002) representation of what in the reality of teaching and learning is complex and messy, which suggests that adaptability and responsiveness to student needs and contexts are prerequisite for the construction of new individual and shared knowledge within the critical realm. We advocate that a critical constructivist framework provides the best opportunity for students to "play" with new ways of thinking within the critical. Developing criticality is a demanding journey with many challenges and although the CAP is not a complete solution to critical theory's pedagogical problems, we view it as a beginning. In this process students should develop the intellectual strategies "to positively meet new challenges" (Kirk, 2006, p. 257), to engage in cultural critique (Kirk, 2006) and be empowered to take some action to contribute to a more socially just world.

\section{CONCLUDING THOUGHTS}

In the last decade, curriculum changes have resulted in teachers of senior secondary school physical education in 
Aotearoa New Zealand and elsewhere being challenged to adopt a pedagogical approach that is more socio-critical. This philosophical shift and the practicalities of implementing meaningful teaching and learning programmes for physical education guided by a socio-critical curriculum has proved challenging. The major challenge is to address the implementation of a sociocritical curriculum and articulate critical pedagogy in senior physical education from a practical pedagogic perspective. To this end we have investigated and devised a process (CAP) that describes critical analysis in senior physical education programmes. Thus we have gone some way to addressing the difficulties of translating theory to practice by helping teachers understand their practice through the use of CAP.

This paper has outlined the application of critical constructivist theory to physical education teaching by introducing a critical analysis process that has been developed over time in our work with teachers and secondary school physical education students. While we have specifically outlined a critical analysis process, we suggest there are key knowledges and understandings that precede successful use of the critical analysis process in learning in senior physical education.

Finally, we have explained the need for such a process as a tool for use in senior physical education, and acknowledge that this is a "work in progress" and additional research will enable further refinements to the model. Informal action research has contributed to the development of the CAP to date and there is a need for further research addressing ways in which critical abilities can be effectively included in PETE professional learning opportunities. Research contributing to the development and maintenance of a critical perspective across the whole physical education programme, not simply in isolated units of work, would be a worthy investigation. This paper reflects our belief in the need for an ongoing focus on developing the pedagogical tools that will support the implementation of a socio-critical curriculum in senior physical education.

\section{REFERENCES}

Azzarito, L., \& Ennis, C. (2003). A sense of connection: toward social constructivist physical education. Sport, Education and Society, 8(2), 179-198.

Beard, C., \& Wilson, J. P. (2002). The power of experiential learning: a handbook for trainers and educators. London, England: Kogan Page.
Biesta, G. (1998). Say you want a revolution ... Suggestions for the impossible future of critical pedagogy. Educational Theory, 48(4), 499-510

Breunig, M. (2009). Teaching for and about critical pedagogy in the post-secondary classroom. Studies in Social Justice, 3(1), 247-262.

Burbules, N., \& Berk, R. (1999). Critical thinking and critical pedagogy: Relations, differences and limits. In T. Popkewitz \& L. Fendler (Eds.), Critical theories in education: Changing terrains of knowledge and politics (pp. 45-65). New York, NY: Routledge.

Burbules, N., \& Rice, S. (1991). Dialogue across difference: Continuing the conversation. Harvard Educational Review, 61(4), 393-416.

Carlson, D. (1998). Finding a voice, and losing our way? Educational Theory, 48(4), 541.

Cassidy, T. (2000). Investigating the pedagogical process in physical education teacher education (Unpublished PhD thesis). Deakin University, Melbourne, VIC, Australia.

Cobb, P. (1996). Where's the mind? A coordination of sociocultural and cognitive perspectives. In C. T. Fosnot (Ed.), Constructivism: Theory, perspectives and practice (pp. 103-119). New York, NY: Teachers College Press.

Culpan, I. (2004). Physical education curriculum development: A humanist positioning. In A. M. O'Neill, J. Clark, \& R. Openshaw (Eds.), Reshaping culture, knowledge and learning: Policy and content in the New Zealand Curriculum Framework. Palmerson North, New Zealand: Dunmore Press.

Culpan, I., \& Bruce, J. (2007). New Zealand physical education and critical pedagogy: Refocusing the curriculum. International Journal of Sport and Health Science, 5, 1-11.

Duncum, P. (2008). Thinking critically about critical thinking: Towards a post-critical, dialogic pedagogy for popular visual culture. International Journal of Education Through Art, 4(3), 247-257.

Duncum, P. (2009). Toward a playful pedagogy: Popular culture and the pleasures of transgression. Studies in Art Education, 50, 232-244.

Fairclough, N. (1992). Discourse and social change. Cambridge, England: Polity Press.

Fairclough, N. (1995). Media discourse. London, England: Edward Arnold.

Fitzclarence, L., \& Tinning, R. (1990) Challenging hegemonic physical education: Contextualizing physical education as an examinable subject. In D. Kirk \& R. Tinning (Eds.), Physical education, curriculum and culture (pp. 169-192). Lewes, England: Falmer Press.

Fitzpatrick, K. (2010) Stop playing up! A critical ethnography of health, physical education and (sub) urban schooling (Unpublished PhD thesis). University of Waikato, Hamilton, New Zealand.

Gorden, W. (2000). Synetics. In B. Joyce, M. Weil, \& E. Calhoun (Eds.), Models of teaching (6th ed.; Pp. 215-245). Needham Heights, MA: Allyn and Bacon.

Gore, J. (1993). The struggle for pedagogies: Critical and feminist discourses as regimes of truth. New York, NY: Routledge.

Green, B. (1998) Teaching for difference: Learning theory and post-critical pedagogy. In D. Buckingham (Ed.), Teaching popular culture: Beyond radical pedagogy (pp. 177-197). London, England: University College Press.

Hinchey, P. (2004). Becoming a critical educator: Defining a classroom Identity, designing a critical pedagogy. New York, NY: Peter Lang.

Kanpol, B. (1999). Critical pedagogy: An introduction (2nd ed.). Westport, CT: Bergin \& Garvey.

Kincheloe, J. L. (2004). Critical pedagogy. New York, NY: Peter Lang.

Kincheloe, J. L. (2005). Critical constructivism primer. New York, NY: Peter Lang.

Kirk, D. (2006). Sport education, critical pedagogy, and learning theory: Toward an intrinsic justification for physical education and youth sport. Quest, 58, 255-264. 
Kohli, W. (1998). Critical education and embodied subjects: Making the poststructural turn. Educational Theory, 48(4), 511-519.

Kraft, R., \& Kielesmeier, J. (Eds.). (1995). Experiential learning in schools and higher education. Dubuque, IA: Kendall/Hunt.

Laker, A. (2003) The future of physical education. Is this the "new pedagogy"? In A. Laker (Ed.), The future of physical education (pp. 153-170). London, England: Routledge.

Leistyna, P., \& Woodrum, A. (1996). Context and culture: What is critical pedagogy? In P. Leistyna, A. Woodrum, \& S. A. Sherblom (Eds.), Breaking free: The transformative power of critical pedagogy (pp. 1-7). Cambridge, MA: Harvard Educational Review.

Light, R., \& Wallian, N. (2008). A constructivist-informed approach to teaching swimming. Quest, 60, 387-404.

Luckner, J. L., \& Nadler, R. S. (1997). Processing the experience: Strategies to enhance and generalise learning. Montecito, CA: Kendall/Hunt.

Macdonald, D. (2002). Critical pedagogy: What might it look like and why does it matter. In A. Laker (Ed.), The sociology of sport and physical education (pp. 167-189). New York, NY: RoutledgeFalmer.

Macdonald, D. (2003). Curriculum change in the postmodern world: Is the school curriculum reform project an anachronism? Journal of Curriculum Studies, 35(2), 139-149.

Macdonald, D., \& Brooker, R. (1999). Articulating a critical pedagogy in physical education teacher education. Journal of Sport Pedagogy, 5(1), 51-63.

Ministry of Education (1999). Health and Physical Education in the New Zealand Curriculum. Wellington, New Zealand: Learning Media.

Ministry of Education (2007). The New Zealand Curriculum. Wellington, New Zealand: Learning Media.

Nemiroff, G. H. (1992). Reconstructing education: Toward a pedagogy of critical humanism. London, England: Bergen \& Garvey.

O'Sullivan, M., Siedentop, D., \& Locke, L (1992). Toward collegiality: Competing viewpoints among teacher educators. Quest, 44, 266-280.

Penney, D., \& Jess, M. (2004). Physical education and physically active lives: A lifelong approach to curriculum development. Sport, Education and Society, 9(2), 269-287.

Pinar, W., Reynolds, W., Slattery, P. \& Taubman, P. (1996) Understanding curriculum. New York, NY: Peter Lang.

Pritchard, A., \& Woollard, J. (2010). Psychology for the classroom: Constructivism and social learning. New York, NY: Routledge.

Prouty, D., Panicucci, J., \& Collinson, R. (Eds.). (2007). Adventure education: Theory and applications. Auckland, New Zealand: Human Kinetics.

Richardson, V. (2003). Constructivist pedagogy. Teachers College Record, 105(9), 1623-1640.

Roberts, P. (2000). Education, literacy and humanization: Exploring the work of Paulo Freire. Westport, CT: Bergin \& Garvey.

Ruiz, B. M., \& Fernandez-Balboa, J. M. (2005). Physical education teacher educators' personal perspectives regarding their practice of critical pedagogy. Journal of Teaching in Physical Education, 24(3), 243-264.

Shor, I. (1996). When students have power: Negotiating authority in a critical pedagogy. Chicago, IL: University of Chicago Press.

Sweet, S. (1998). Practicing radical pedagogy: Balancing ideals with institutional constraints. Teaching Sociology, 26, 100-111.

Tinning, R. (2002). Toward a "modest pedagogy": Reflections on the problematics of critical pedagogy. Quest, 54, 224-240.

Watkins, C. (2005). Classrooms as learning communities:What's in it for schools? London, England: RoutledgeFalmer.
Watkins C., \& Mortimore, P. (1999). Pedagogy: What do we know? In P. Mortimore (Ed.), Understanding pedagogy and its impact on learning (pp. 1-19). London, England: Paul Chapman.

Weiler, K. (1991). Freire and a feminist pedagogy of difference. Harvard Educational Review, 61(4), 449-474.

Wright, J. (2004). Critical inquiry and problem solving in physical education. In J. Wright, D. Macdonald, \& L. Burrows (Eds.), Critical inquiry and problem solving in physical education (pp. 3-16). New York, NY: Routledge. 